prof. zw. dr hab. Grażyna BORYS

Wydział Ekonomii, Zarządzania i Turystyki w Jeleniej Górze, Uniwersytet Ekonomiczny we Wrocławiu

e-mail: grazyna.borys@ue.wroc.pl

dr hab. Teresa ORZESZKO, prof. UEW

Wydział Ekonomii, Zarządzania i Turystyki w Jeleniej Górze, Uniwersytet Ekonomiczny we Wrocławiu

e-mail: teresa.orzeszko@ue.wroc.pl

DOI: $10.15290 /$ ose.2017.01.85.06

\title{
KONCEPCJA PAŃSTWOWEGO BILANSU GEOLOGICZNO-GÓRNICZEGO
}

\author{
Niewatpliwie ważniejsza jest sama rzecz niż \\ stowa uizyte do jej wyrażenia (...). Jednak.że stan \\ terminologii nie pozostaje bez wplywu na wartosíc \\ formutowanego pray jej pomocy poznania.
}

Stanisław Kamiński

\section{Streszczenie}

Celem artykułu jest wypracowanie ogólnych założeń koncepcji bilansu geologiczno-gómiczego, którego obowiązek sporządzania w cyklach rocznych spoczywałby na rządowej administracji publicznej. Jego przedmiotem jest prezentacja kontekstu wysunięcia tej koncepcji, która wyjaśnia istotę, przeznaczenie i cel sporządzania bilansu, jak również propozycja jego ramowej konstrukcji .

Słowa kluczowe: bilans geologiczno-górniczy, aktywa geologiczno-gómicze Skarbu Państwa, tantiemy za wykorzystanie aktywów geologiczno-górniczych Skarbu Państwa

\section{CONCEPT OF STATE GEOLOGICAL AND MINING BALANCE}

\section{Summary}

The purpose of the paper is to discuss the general assumptions underlying the concept of geological and mining balance, which the state's public administration would be obliged to prepare in annual cycles. The author presents the context for suggesting this concept, which explains the essence, the role and the goal behind the preparation of the discussed balance, as well as a proposal for its framework construction.

Key words: geological and mining balance, geological and mining assets of State Treasury, royalties for using geological and mining assets of State Treasury

JEL: H83, K32, Q56 


\section{Wstęp}

Słowo 'bilans' powszechnie wyprowadza się od włoskiego słowa bilancia (waga), lecz równoważne są hipotezy o jego źródle łacińskim lub francuskim. Łacińskie bilans pochodzi od wyrazów bis (dwukrotnie) i lanx (szala wagi), co oznacza równowagę, równość. Francuskie zaś bilan jest słowem dwuczłonowym, złożonym z bil i an (skrótowo rok). Zatem bilans może być utożsamiany z pewnym obrachunkiem rocznym [Pogodzińska-Mizdrak, 2009, s. 132].

We współczesnym języku polskim pojęcie bilansu ma charakter interdyscyplinarny, tzn. bywa używane zarówno w języku potocznym, jak i w językach branżowych (specjalistycznych, dziedzinowych), przy czym w ich obrębie czasami w rozmaitym sensie. $\mathrm{Na}$ gruncie rachunkowości pojęcie bilansu odnosi się do jednego z kluczowych elementów sprawozdania finansowego jednostki, w którym wykazuje się stany aktywów i pasywów na dzień kończący bieżący i poprzedni rok bilansowy, ponadto, zgodnie $\mathrm{z}$ art. 3 ust. 1 pkt. 12 Ustany z dnia 29 wrresésnia 1994 roku o rachunkowości, aktywa to: kontrolowane przez jednostke zasoby majatkowe o wiarygodnie określonej wartości, powstate w wyniku przeszlych zdarzeń, ketóre spowoduja w prayszz̨ości wplyw do jednostki korayści ekonomicznych. Natomiast przez pasywa rozumie się określone wartościowo źródła finansowania aktywów.

W literaturze ekonomicznej i praktyce gospodarczej bilans jest również pojmowany jako pewnego rodzaju zestawienie (także opisowe) przeciwstawnych kategorii albo obrachunek o charakterze porównawczym. W tym znaczeniu pojęcie bilansu coraz częściej pojawia się m.in. w literaturze z zakresu zarządzania środowiskiem, czego przykładem jest bilans ekologiczny (przedsiębiorstwa, procesów, produktów) czy krajowy bilans złóż kopalin. W ujęciu najbardziej ogólnym bilans ekologiczny jest tabelarycznym zestawieniem strumieni materiałów i energii - (ujętych ilościowo lub/i wartościowo) o charakterze wejściowym (imput) i wyjściowym (output) - pochodzących z określonych przedsiębiorstw, procesów czy produkcji określonych produktów. Celem tego zestawienia jest ocena oddziaływania przedsiębiorstw (procesu, produkcji/produktu) na środowisko przyrodnicze [Strebel, 2003, s. 305-306]. Bilans zasobów złóż kopalin jest coroczną publikacją nieprzerwanie ukazującą się od 1953 roku. Zawiera ona tabelaryczno-opisowe zestawienia o udokumentowanych zasobach złóż kopalin, stanie ich zagospodarowania oraz wielkości wydobycia kopalin ze złóż. Jest ona równocześnie wyposażona w komplet map z lokalizacją większości złóż. Analizy przywołanego bilansu są wykorzystywane w procesach zarządzania złożami kopalin w Polsce i ich ochrony [Bilans zasobón złtóz kopalin w Polsce ..., 2015, s. 5].

Celem artykułu jest wypracowanie ogólnych założeń koncepcji bilansu geologiczno-górniczego, którego obowiązek sporządzania w cyklach rocznych powinien spoczywać na rządowej administracji publicznej. Jego przedmiotem jest prezentacja kontekstu wysunięcia tej koncepcji, która wyjaśnia jego istotę, przeznaczenie i cel sporządzania bilansu, a także ramowa propozycja jego konstrukcji. Realizacji celu posłużył przegląd i analiza literatury, odpowiednich regulacji oraz innych dokumentów. 


\section{Kontekst wysunięcia koncepcji państwowego bilansu geologiczno- -górniczego}

Postuluje się coroczne opracowywanie przez rządową administrację i przedkładanie szerokiej opinii publicznej bilansu geologiczno-górniczego. Przez to pojęcie należy rozumieć dwustronne zestawienie, w którym po lewej stronie byłyby ujawniane aktywa geologiczno-górnicze Skarbu Państwa (AGG SP), a po prawej - tantiemy za ich wykorzystywanie oraz inne dochody publiczne z tym związane. Bilansem mogłaby być także objęta informacja dodatkowa, np. o metodach wyceny poszczególnych składników aktywów czy ilości udzielonych koncesji na poszukiwanie lub rozpoznawanie złóż kopalin objętych katalogiem własności górniczej oraz na wydobywanie kopalin z tych złóż. Celem sporządzania bilansu geologiczno-górniczego powinno być pozyskiwanie wartościowej informacji do analizy i oceny efektywności gospodarowania złożami Skarbu Państwa i informacją geologiczna, do której prawo przysługuje Skarbowi Państwa w warunkach zrównoważonego rozwoju.

Wysunięcie koncepcji państwowego bilansu geologiczno-górniczego zostało spowodowane trzema podstawowymi przesłankami. W pierwszej kolejności należy zwrócić uwagę na zapowiedź likwidacji w 2017 roku Ministerstwa Skarbu Państwa. Obecnie Minister Skarbu Państwa, zgodnie z dyspozycja art. 2 pkt. 1 Ustawy z dnia 8 sierpnia 1996 roku o zasadach wykonywania uprawnień praystugujacych Skarbowi Państwa, przygotowuje i przedkłada Radzie Ministrów oraz - z jej upoważnienia - Sejmowi coroczne sprawozdanie o stanie mienia Skarbu Państwa, jak również o: ekonomicznych, finansowych i społecznych skutkach prywatyzacji. Sprawozdanie to jest dostępne opinii publicznej za pośrednictwem Internetu. Prezentuje ono mienie Skarbu Państwa w ujęciu zbiorczym, syntetycznym i statycznym, według stanu na określony dzień, na podstawie dokumentów będących źródłem informacji zbiorczej. Celem sprawozdania jest przedstawienie informacji o majątku Skarbu Państwa - jego stanie prawnym, strukturze, wartości. Elementem tego majątku są m.in. zasoby naturalne (dobra naturalne w stanie nieprzetworzonym, które mogą być dostępne dla ludności bez ograniczeń w celach niekomercyjnych, ale ich wykorzystywanie gospodarcze wymaga uzyskania koncesji bądź pozwolenia), w tym kopaliny. Likwidacja Ministerstwa Skarbu Państwa, a w konsekwencji zniesienie obowiązku sprawozdawczego przypisanego teraz Ministrowi Skarbu Państwa oznaczałoby znaczące ograniczenie dostępu do informacji o stanie strategicznych zasobów kraju, pozostających pod szczególną ochroną prawną, zgodnie z Ustawa z. dnia 6 lipca 2001 roku o zachowaniu narodowego charakteru strategicznych zasobów naturalnych, dla organu przedstawicielskiego, jakim jest Sejm i innych grup interesariuszy (potencjalnych inwestorów, instytucji finansowych, organizacji ekologicznych itp.). Należy przy tym zaznaczyć, że układ obecnie przygotowywanego i przedkładanego Radzie Ministrów sprawozdania różni się od zgłaszanej koncepcji bilansu geologiczno-górniczego.

Drugim powodem zgłoszenia koncepcji bilansu geologiczno-górniczego jest fakt, że złoża kopalin, bez względu na formę ich własności, są powszechnie postrzegane jako obiekty driałalności gospodarczej poddane regułom gospodarki rynkowej [Nieć, Radwanek-Bakk, 2014, s.11], a zatem takie, których poszukiwanie i eksploatacja powinna przynosić 
korzyści finansowe. Zgodnie z art. 6 ust. 1 pkt. 19 Ustany z. dnia 9 czervwca 2011 roku. Prawo geologiczne i górnicze, złożem kopaliny jest naturalne nagromadzenie materiałów, skał i innych substancji, których wydobywanie może przynieść korzyść gospodarczą. W korzyściach finansowych powinny partycypować zarówno przedsiębiorstwa poszukiwawcze i wydobywcze (w formie zysków), jak i ich właściciele (w formie tantiem). Złoża kopalin, stanowiące własność Skarbu Państwa, mają charakter narodowy. Stąd spoleczeństwo powinno mieć dostęp do informacji o korzyściach finansowych związanych z ich posiadaniem i gospodarczym wykorzystywaniem, a tym samym o efektywności ekonomicznej gospodarki złożami kopalin. Ujawnianie tantiem z tytułu eksploatacji kopalin stanowiących mienie Skarbu Państwa oraz dochodów z udostępniania informacji geologicznej można uznać za przejaw stosowania się do zasad dobrego rządzenia w sektorze publicznym (good governance), a zwłaszcza zasady otwartości oraz rozliczalności administracji i władz publicznych [Szumowski, 2014, s. 95].

Z tą przesłanką wysunięcia koncepcji państwowego bilansu geologiczno-górniczego w pewnym stopniu koresponduje kolejna - potrzeba zapewnienia przejrzystości sektora poszukiwawczego i wydobywczego. $\mathrm{Na}$ tę potrzebę zwrócili uwage już na przełomie lat pięćdziesiątych i sześćdziesiątych XX wieku badacze ekonomii rozwoju oraz międzynarodowych stosunków gospodarczych. Zauważono bowiem, że w wielu krajach bogatych w surowce i specjalizujących się w ich eksporcie są notowane gorsze wyniki rozwoju gospodarczego niż w państwach, których zasobność jest znikoma [Sialitskaya, 2013, s. 5]. Zjawisko to jest nazywane w literaturze przedmiotu „klątwą bogactwa” (resource curse) lub „paradoksem obfitości” (paradox of plenty). Lączy ono w sobie aspekty: ekonomiczne, społeczne i kulturowe, polityczne i ekologiczne, a jest wywoływane, w zależności od kraju, różnymi przyczynami (w tym m.in.: korupcją, klientyzmem politycznym, monokultura gospodarcza, pogonią za renta, degradacja środowiska przyrodniczego). Zjawisko „paradoksu obfitości” prowadzi do obniżania dobrobytu społecznego w krajach zamożniejszych, a krajom rozwijającym się uniemożliwia wyjście z „pułapki zadłużenia i biedy”.

W tym kontekście, pod naciskiem międzynarodowej opinii publicznej, powstała międzynarodowa organizacja pod nazwą Inicjatywa na rzecz Przejrzystości Sektorów Wydobywczych (Extractive Industries Transparency Initiative - EITI). Zajmuje się ona promocja przejrzystości, odpowiedzialności i dobrego zarządzania w odniesieniu do zasobów naturalnych. Określa ona samą siebie jako koalicję wielu interesariuszy złożoną z:

- $\quad$ rządów krajów (17, w tym w większości najbardziej rozwiniętych, takich jak: USA, Kanada, Japonia, Australia, Wielka Brytania, Niemcy);

- $\quad$ przedsiębiorstw (86 największych przedsiębiorstw branży wydobywczej);

- inwestorów instytucjonalnych (95 instytucji zarządzających łącznie aktywami o wartości ponad 18 bln USD);

- $\quad$ społeczeństwa obywatelskiego (9 organizacji zajmujących się pomocą krajom ubogim - m.in. Caritas oraz przejrzystością - m.in. Transparency International, Oxfam);

- organizacji partnerskich (21 organizacji, wśród których przykładowo można wymienić: grupę G7, G20, Europejski Bank Inwestycyjny, Komisję Euro- 
pejska, Grupę Banku Światowego, Międzynarodowy Fundusz Walutowy, OECD).

Extractive Industries Transparency Initiative wydaje standardy, a ich wdrażaniem mają zajmować się rządy krajów bogatych w zasoby naturalne. Standardy EITI mają na celu realizację 12 podstawowych zasad, które koncentrują się wokół informacji o: zasobach naturalnych, ich wykorzystaniu oraz przepływie środków pieniężnych związanych $z$ ich wydobywaniem i sprzedażą. Informacje są dostarczane wszystkim zainteresowanym stronom, $w$ tym przede wszystkim obywatelom państw dysponujących zasobami złóż i organizacjom społecznym. Z informacji mogą również korzystać inwestorzy i same przedsiębiorstwa wydobywcze, ponieważ wśród zasad EITI zapisano konieczność uzgadniania płatności przedsiębiorstw wydobywczych z wpływami administracji publicznej poszczególnych państw zasobnych w złoża kopalin. Ponadto, państwa, które zadeklarowały wolę wprowadzenia standardów EITI do praktyki, są zobowiązane do ujawniania kierunków wykorzystania środków z płatności wydobywczych, jeżeli mają one specjalne przeznaczenie. Przejrzystość informacji ma prowadzić do osiagnięcia zasadniczego celu działania organizacji, jakim jest ostrożne wykorzystywanie zasobów naturalnych, zgodne z zasadami zrównoważonego rozwoju [The EITI Standard 2016 ...].

Warto podkreślić, że konieczność zapewnienia przejrzystości płatności na rzecz administracji publicznej przez jednostki duże i jednostki zainteresowania publicznego została dostrzeżona przez Komisję Europejską oraz wprowadzona do europejskiego porządku prawnego na mocy Dyrektyny Parlamentu Europejskiego $i$ Rady 2013/34/UE [s. 19-76], a tym samym i do polskiego porządku prawnego na mocy znowelizowanej Ustany o rachunkowości z dnia 29 września 1994 roku [2016].

Wprowadzenie koncepcji bilansu geologiczno-górniczego do praktyki gospodarczej oznaczałoby respektowanie podstawowych zasad dobrego rządzenia w polskim sektorze publicznym - zasady przejrzystości, transparentności, rozliczalności władz publicznych za racjonalna, rozważna gospodarkę złożami kopalin należących do Skarbu Państwa. Przestrzeganie tych zasad powinno wymusić szerokie wykorzystanie rachunku ekonomicznego w procesie budowy i wdrażania polityki gospodarowania złożami, a także wpłynąć na dynamiczny rozwój teorii tego rachunku, która praktycznie jest nieobecna w polskiej literaturze ekonomicznej.

\section{Konstrukcja bilansu geologiczno-górniczego}

Jak już wspominano, po lewej stronie postulowanego państwowego bilansu geologiczno-górniczego powinna być ujawniana wartość aktywów geologiczno-górniczych Skarbu Państwa. Termin aktywa geologiczno-gónnicze Skarbu Państwa w krajowej literaturze naukowej po raz pierwszy pojawił się w tytule artykułu autorstwa J. Stefanowicza, opublikowanym w 2010 roku w „Biuletynie Państwowego Instytutu Geologicznego. Artykuł jest: (...) prezentacja i rozważaniem nad ujeciem aktywón, csyli mienia (wtasności i innych praw majatkonych) Skarbu Pansstwa w obszarze zasobów naturalnych, driatalności geologicznej i górniczej, na praylktadzie Sprawozdania o stanie mienia Skarbu Państwa 
na dzień 31 grudnia 2008 roku, praygotowanego prezez Ministra wtaściwego do spraw Skarbu Państwa dla Sejmu Rzeczopospolitej Polskiej (...) [Stefanowicz, 2010 s. 220]. Jednak autorowi nie udało się zaproponować precyzyjnej definicji omawianej kategorii aktywów. O jej zawartości można wnioskować dopiero po lekturze całego opracowania, w którym jest ona opisywana w kilku miejscach i za każdym razem w nieco inny sposób. Wydaje się, że J. Stefanowicz utożsamia wspomniane aktywa zasadniczo z majątkiem trwałym Skarbu Państwa (SP) w postaci praw do: własności złóż kopalin, informacji geologicznej, części górotworu wraz z wyrobiskami, praw z umów długoterminowych. Ponadto, można także domniemywać, że obejmuje on tą kategorią również przynależne Skarbowi Państwa należności, w szczególności z tytułu: użytkowania górniczego; eksploatacji złóż stanowiących własność SP; udostępniania informacji geologicznej; udostępniania do korzystania wyrobisk i części gruntów poza złożami, do których prawa przysługują SP.

Wydaje się, że wzmiankowany autor w określaniu rodzajowego zakresu AGG SP inspirował się legalną definicją aktywów jednostki. Warto przypomnieć, że do tych aktywów zalicza się zasoby majątkowe (składniki majątku), które spełniaja jednocześnie cztery warunki: powstały w wyniku przeszłych zdarzeń; mają wiarygodnie określoną wartość; pozostaja pod kontrolą jednostki; przyniosą w przyszłości korzyści ekonomiczne. Należy zauważyć, że zasoby złóż kopalin są nieodnawialnym darem natury i jedynie ich poszukiwanie i dokumentowanie oraz udostępnianie do gospodarczego wykorzystania pod postacią surowców wymaga nakładów rzeczowych i finansowych, stąd wiarygodne ustalenie ich wartości jest niezwykle trudnym zadaniem. Co więcej, złoża kopalin SP nie pozostają pod kontrola jednej jednostki. Gospodarka tymi złożami nie stanowi kompleksowego zadania publicznego, przypisanego jednemu organowi władzy publicznej lub instytucji centralnej. Aktualnie sprawy zarządu złożami są rozrzucone pomiędzy kompetencje pięciu ministrów [Stefanowicz, Galos, 2014, s. 251]. Sam Skarb Państwa nie został na gruncie polskiego prawa zdefiniowany, chociaż art. 218 Konstytucji Rzecsypospolitej Polskiej [1997] stanowi, że organizację Skarbu Państwa oraz sposób zarządzania majątkiem SP określa ustawa. Tylko niektóre aspekty funkcjonowania SP sa wyznaczone w przepisach, m.in. w Ustawie z dnia 23 kwietnia 1964 roku. Kodeks cywilny czy Ustawie z dnia 8 sierpnia 1996 roku o zasadach mykonywania uprawnień praystugujacych Skarbowi Państwa. Informacje na temat praw własności do poszczególnych złóż kopalin czy wyrobisk poeksploatacyjnych nie są uwzględniane ani w Bilansie Zasobów Kopalin, ani w bazie danych systemu „Gospodarki i Ochrony Bogactw Naturalnych Polski MIDAS”, ani też w żadnych innych dokumentach zbiorczych na temat złóż kopalin w Polsce. Dotychczas nie wykształciła się również praktyka wyceny złóż kopalin należących do SP i informacji geologicznej na potrzeby sprawozdawczości publicznej, choć w literaturze przedmiotu pojawiły się opracowania przyczynkarskie na ten temat [Wirth, Kudełko, Wanielista, 2009, s. 21; Uberman, 2011, s. 64]. W 2008 roku przez Polskie Stowarzyszenie Wyceny Złóż Kopalin został opracowany Kodeks Wyceny Złóż Kopalin POLVAL, który ma jednak charakter uniwersalny w tym sensie, że abstrahuje od celów wyceny, które mogą być bardzo różne (transakcyjne, spór sądowy, ustalenie renty górniczej, zabezpieczenie kredytu itd.). Wydaje się zatem, że AGG SP powinny być wyjęte spod reżimu ustawy o rachunkowości i odrębnie zdefiniowa- 
ne. Postuluje się, by tym terminem obejmować zasoby złóż kopalin SP i informację geologiczną w ujęciu wartościowym.

Własnością Skarbu Państwa są objęte:

- złoża: węglowodorów, węgla kamiennego, metanu występującego jako kopalina towarzysząca, węgla brunatnego, rud metali z wyjątkiem darniowych rud żelaza, metali w stanie rodzimym, rud pierwiastków promieniotwórczych, siarki rodzimej, soli kamiennej, soli potasowej, soli potasowo-magnezowej, gipsu i anhydrytu, kamieni szlachetnych, bez względu na miejsce ich występowania;

- części górotworu położone poza granicami przestrzennymi nieruchomości gruntowej, w szczególności znajdujące się w granicach obszarów morskich Rzeczypospolitej Polskiej;

- złoża: wód leczniczych, wód termalnych i solanek.

Drugim składnikiem AGG SP powinna być, ujęta wartościowo, informacja geologiczna. Informacja geologiczną są dane i próbki wraz z wynikami ich przetworzenia i interpretacji, zwłaszcza przedstawione w dokumentacjach geologicznych (geologicznej złoża kopalin, geologiczno-inwestycyjnej złoża węglowodorów, hydrologicznej, geologiczno-inżynierskiej i innych) oraz zapisane na informacyjnych nośnikach danych. Organy administracji geologicznej i państwowa służba geologiczna gromadza, ewidencjonuja, archiwizuja, chronią i udostępniają informację geologiczna.

Na potrzeby bilansu należałoby oczywiście wypracować metody wyceny obu rodzajów AGG SP, przy czym trzeba byłoby zastosować odrębne metody dla złóż udokumentowanych, ale jeszcze nieeksploatowanych, a także złóż będących w eksploatacji.

Po prawej stronie państwowego bilansu geologiczno-górniczego powinny być ujmowane tantiemy za korzystanie ze złóż kopalin SP i inne opłaty z tym związane oraz dochody publiczne za korzystanie z informacji geologicznej. W ujęciu słownikowym termin tantiemy stosuje się do określania opłat za wykorzystywanie: aktywów, własności intelektualnej albo praw pobieranych przez licencjodawcę od licencjobiorcy. Tantiemy dotyczą m.in.:

- praw autorskich,

- patentów,

- znaków handlowych,

- praw do badania i eksploatacji złóż surowców naturalnych.

W literaturze angielskojęzycznej tantiemy, odnoszące się do badania i eksploatacji złóż kopalin, powszechnie określa się terminem royalty [Stownik finansony polsko-angielski]. Według Banku Światowego, za rotality należy uznać podatki i opłaty, których celem jest zrekompensowanie właścicielowi utraconych bezpowrotnie złóż lub które są specyficzne dla sektora poszukiwawczo-górniczego. Wydaje się, że ten warunek spełniają:

- $\quad$ wynagrodzenia za ustanowienie użytkowania górniczego;

- opłaty eksploatacyjne;

- $\quad$ specjalny podatek weglowodorowy, obowiazujący na mocy Ustany z dnia 25 lipca 2014 roku o specjalnym podatku weglowodoronym (podatek od zysków z działalności wydobywczej węglowodorów na terytorium Rzeczypospolitej Polskiej); 
- $\quad$ podatek od wydobycia niektórych kopalin, opłacany na mocy Ustawy z dnia 2 marca 2012 roku o podatku od wydobycia niektórych kopalin.

Ponadto, po lewej stronie bilansu powinny być ujawnione opłaty skarbowe za udzielenie: koncesji na wydobywanie kopaliny ze złoża, koncesji na poszukiwanie i rozpoznawanie złoża węglowodorów lub decyzji inwestycyjnej na wydobywanie węglowodorów ze złóż, a także wynagrodzenia za korzystanie z informacji geologicznej.

\section{Podsumowanie}

Problematyka gospodarowania złożami kopalin i informacją geologiczną bardzo często jest pomijana w krajowych publikacjach z zakresu kształtowania i zarządzania środowiskiem. Nieustannie brakuje również kompleksowej polityki państwa w zakresie gospodarowania i ochrony strategicznych zasobów rodzimych złóż w warunkach zrównoważonego rozwoju, choć zostały podjęte pewne działania w kierunku jej stworzenia, m.in. została opracowana Biała Ksiega Ochrony Złóż Kopalin [2015]. Zgłoszona koncepcja państwowego bilansu geologiczno-górniczego może być wykorzystana zarówno na etapie formułowania tej polityki, jak i na etapie monitorowania postępów jej realizacji.

\section{Wkład autorów w powstanie artykułu}

prof. zw. dr hab. Grażyna Borys - koncepcja artykułu, streszczenie, wstęp, pierwszy rozdział - 50\%

dr hab. Teresa Orzeszko, prof. UEW - przegląd literatury przedmiotu, drugi rozdział, podsumowanie, edycja tekstu $-50 \%$

\section{Literatura}

Biała Ksiega Ochrony Złóż Kopalin, 2015, Ministerstwo Środowiska, Warszawa.

Bilans zasobów złóż kopalin w Polsce wg stanu na 31 XII 2014, 2015, M. Szuflicki, A. Malon, M. Tymiński (red.), Wydawnictwo PIG PIB, Warszawa.

Dyrektywa Parlamentu Europejskiego $i$ Rady 2013/34/UE w sprawie rocznych sprawozdan finansowych, skonsolidowanych sprawozdań finansowych i powiazanych sprawozdań niektórych rodzajów jednostek, zmieniajaca dyrektywe Parlamentu Europejskiego i Rady 2006/43/WE oraz uchylajaca dyrektywy Rady 78/660/EWG i 83/349/EWG zdnia 26 czerwca 2013 roku, Dz. Urz. UE L, 2013, Nr 182.

Konstytucja Rzueczpospolitej Polskiej z dnia 2 kwietnia 1997 roku, Dz. U. 1997, Nr 78, poz. 483 ze zm.

Nieć M., B. Radwanek-Bąk B., 2014, Ochrona i racjonalne wykoraystywanie złóż kopalin, Wydawnictwo IGSMiE PAN, Kraków. 
Pogodzińska-Mizdrak E., 2009, Informacyjna rola bilansu w historycznej perspektywie, „Zeszyty Teoretyczne Rachunkowości", t. 51(107).

Sialitskaya Y., 2013, Klatwa bogactwa a polityka gospodarcza państwa, rozprawa doktorska, Wydawnictwo Uniwersytetu Ekonomicznego w Poznaniu, Poznań.

Stownik finansowy polsko-angielski, http://www.findict.pl/słownik (data wejścia: 20.06. 2016).

Stefanowicz J., 2010, Aktywa geologiczno-górnicze Skarbu Państwa, „Biuletyn Państwowego Instytutu Geologicznego", nr 439.

Stefanowicz J., Galos K., 2014, Kierunki zarzqdzania zasobami kopalin mineralnych z.punktu widzenia Skarbu Państwa jako właściciela złóż kopalin objetych własnościa górniczq „Zeszyty Naukowe Instytutu Gospodarki Surowcami Mineralnymi i Energią Polskiej Akademii Nauk", nr 88.

Strebel H., 2003, Ekobilansowanie, [w:] Miedzynarodowe zarzadzanie środowiskiem. Operacyjne zarzqdzanie środowiskiem w aspekcie mięzynarodowym i interdyscyplinarnym, t. 3, M. Kramer, H. Strebel, L. Buzek (red.), Wydawnictwo C.H. Beck, Warszawa.

Szumowski W., 2014, Zarzqadzanie publiczne - próba systematyzacji koncepcï, „Nauki o Zarządzaniu", nr 4 (21).

The EITI Standard 2016. Extractive Industries Transparency Initiative, http:/ / english-eitistandard_0 (data wejścia: 20.06.2016).

Uberman R., 2011, Ocena praydatności podejścia kosz̨owego do wyceny aketywów geologiczno-górniczych, „Gospodarka Surowcami Mineralnymi”, t. 27, z. 2.

Ustawa Kodeks cywilny z.dnia 23 kwietnia 1964 roku, t.j. Dz. U. 2016, poz. 380 ze zm.

Ustawa o podatku od wydobycia niektórych kopalin z dnia 2 marca 2012 roku, t.j. Dz. U. 2016, poz. 1581.

Ustawa o rachunkowości z. dnia 29 września 1994 roku, t.j. Dz. U. 2016, poz. 1047 ze zm.

Ustawa o specjalnym podatku weglowodorowym z dnia 25 lipca 2014 roku, t.j. Dz. U. 2016, poz. 979.

Ustawa o zachowaniu narodowego charakteru strategicznych zasobów naturalnych z dnia 6 lipca 2001 roku, Dz. U. 2001, Nr 97, poz. 1051 ze zm.

Ustawa o zasadach wykonywania uprawnień przystugujacych Skarbowi Państwa z. dnia 8 sierpnia 1996 roku, t.j. Dz. U. 2016, poz. 154 ze zm.

Ustawa Prawo górnicz̨e i geologiczne z. dnia 9 czerwuca 2011 roku, t.j. Dz. U. 2016, poz. 1131.

Wirth H., Kudełko J., Wanielista K., 2009, Metoda wyceny ak.tywów geologiczno-górniczych, „Gospodarka Surowcami Mineralnymi”, t. 25, z. 3. 